\title{
Эволюция ассоциированных форм предприятий и института акции. Опыт торговой отрасли, X-XVIII века
}

\author{
Криничанский К.В. ${ }^{9}$
}

В работе излагаются результаты исследования эволючии ассочиированных форм предприятий и основополагающие начала института акции. Исследуемый период - XXVIII века. Раскрыты и обобщены основные экономические, институциионально-правовые и исторические факторы и предпосылки формирования деловых предприятий в торговой отрасли. Осуществлен сравнительный анализ основных организачионных форм ассочиированного хозяйствования (деловых предприятий) несемейного типа, таких как гильдии, комменда, акиионерная компания и др. Сравнение осуществляется в части мотивов участников (учредителей) предприятий; принциипов организации, определяющих разные способы управления рисками; срочности контрактов, лежащих в основе учреждения предприятий; степени свободы участников, в томчисле свободы распоряжения инвестированным капиталом. Представлены модели эволющии корпорации и эволющии системы контрактации института комменды. Разработана периодизация прочесса зарождения, развития, заката или трансформаций ассоциированных организачионноправовых форм предприятий, дополненная экспресс-характеристикой каждой из форм.

\section{1. Ассоциированные формы хозяйствования. Понятия. Правовые и экономические факторы и предпосылки становления}

Для того чтобы проанализировать эволюцию института акции, требуется в определенной последовательности раскрыть генезис развития ассоциированных форм хозяйствования и отношений совладения ${ }^{10}$, обнаружить правовые основания для создания акции как самостоятельного юридического инструмента, обладающего качеством оборотоспособности, раскрыть влияние развития организованной рыночной торговли на данный инструмент. Исходным историческим пунктом анализа целесообразно выбрать период роста городов в Европе в конце I - начале II тысячелетия н. э. Значимым явлением этого времени было зарождение особых ассощиащий внутри городских общин, объединявших различные группы их жителей, а также образование форм деловых предприятий (товариществ, компаний и т. п.), которые допускали совместное хозяйствование, выходящее за рамки семьи.

С известной долей условности основы ассоџиированного хозяйствования можно разделить на правовые и экономические. Начнем с анализа первых. Понятие и конструкция юридического лица были изобретены римлянами. В период V-XI веков этот опыт в Европе почти не был востребован. Важным препятствием к образованию ассоциированных форм предприятий было общественное устройство, построенное на сильном авторитете, неограниченных полномочиях и превосходящей социальной инициативе светской (по сути, военной) власти. Однако к Х веку в Европе значительно укрепились позиции другого центра силы, который смог противопоставить себя светской власти. Этим центром была церковь. Из детального изложения Г.Дж. Берманом истории и последствий так называемой «папской революции», длившейся на протяжении периода по меньшей мере с 1075-го по 1122 год [Берман, 1998; Berman H.J., 1983], можно заключить, что дорога к практике учреждения

\footnotetext{
9 Доцент кафедры финансов и права Уральского государственного университета им. А.М. Горького.

${ }^{10} \mathrm{~B}$ нашем случае совладение - такая сумма отношений, которая означает образование единого юридического лица (хозяйственного товарищества и общества) за счет аккумуляции капитала иных лиц (учредителей, участников) с последующим наделением этих лиц имущественными и неимущественными правами, вытекающими из их участия в капитале образованного таким образом лица.
} 
корпораций (в том числе их разновидностей, проникших в область коммерции) была проложена церковью, которая использовала модель корпорации, корпоративного правового образования (universitas) как адекватную конструкцию для обозначения своего места и функций в общественной структуре.

Успех последующей практики учреждения корпораций был обеспечен тем, что сформированные церковью основы корпоративного права имели важные отличия от положений римского права, представленного в Кодексах Юстиниана и Феодосия. Выделим два из них. Bo-nервых, церковь (каноническое право) отвергла распространенную ранее точку зрения на предмет свободы учреждения корпораций. Римским правом устанавливалось, что помимо публичных корпораций (государственные институты, города, церкви) «только коллегии, признанные в качестве корпораций императорской властью, могут иметь привилегии и свободы корпораций». По каноническому праву, «любая группа лии, имевщая требуемую организацию и иель... составляла корпорацию, не нуждаясь для этого в специальном разрешении вышестоящей власти» [Берман, 1998]. Во-вторых, каноническое право отвергло точку зрения римского права, согласно которой корпорация может действовать только через своих представителей, но не через совокупность членов. Вместо этого в ряде ситуаций требовалось определенным образом установленное согласие членов корпорации.

Эти определения становились важной основой расширения «учредительской активности», что наблюдалось в последующие века не только в появлении и укреплении новых орденов и монастырей, но и в появлении новых городов и обретении городами особого корпоративного статуса; наконец, в образовании хозяйственных сообществ гильдий, товариществ, компаний, обладающих самостоятельным юридическим статусом. Следует подчеркнуть, что первоначальное употребление понятия «корпорация» в большей мере означало публичный, нежели частный институт. Даже в XIX веке подобным образом логика рассуждений строится И.Т. Тарасовым, четко различающим термины «корпорация», «общество», «акционерная компания» и «товарищество», выделяющим некоторые формы предприятий как переходные от корпораций к компаниям ${ }^{11}$ [Тарасов, 1878, 2000 и др.]. Однако определение корпорации, взятое из документов, принадлежавших к каноническому праву, представляется вполне достаточным для объяснения правовых основ последующей эволюции корпораций в формы частных компаний. Современный этап такой эволюции привел к стиранию границ понятий «корпорация» и «акционерная компания», что позволяет рассматривать их как сходящиеся к единой форме эволюционирующие институты ${ }^{12}$.

\section{2. Факторы и предпосылки генезиса ассоциированных предприятий в торговой отрасли}

Экономические, правовые и исторические факторы и предпосылки появления ассоциированных предприятий в торговой отрасли, точнее в сегменте трансграничных обменов, представлены в табл. 1. Становление и развитие данного сегмента требовало решения сложной финансовой задачи. С одной стороны, трансграничная торговля, относительно крупная и весьма рискованная, требовала больших затрат; с другой — как правило, особенно на ранней стадии, к данному делу приступали небогатые люди низкого сословного положения. Эти обстоятельства выступают наиболее очевидными в объяснении

\footnotetext{
11 Кроме того, И.Т.Тарасов употребляет по отношению к акционерным компаниям словосочетания «модифицированной корпорации» или «не полной корпорации», указывая на обнаружение в них «частнообщественных» черт, единства юридического лица и корпорации [Тарасов, 1878, 2000].

${ }^{12}$ Сказанное относится к пониманию этого процесса экономистами. В юридической литературе к категории «корпорация» могут относиться такие формы, как полные и коммандитные товарищества, общества с ограниченной и с дополнительной ответственностью, акционерные общества, кооперативы, общественные и религиозные организации, некоммерческие организации (фонды, партнерства и пр.), объединения юридических лиц (ассоциации и союзы).
}

Выпуск \#2(6), 2008 
попыток создания в период X-XI веков институтов ассоциированного ведения дел, появления долевых предприятий и страхования как закономерного явления.

В этот период наиболее заметным явлением в эволюции экономической организации стало появление гильдий. Основным мотивом в данном процессе, как правило, было стремление членов гильдий к обеспечению себя и своих семей элементарными средствами к существованию. Однако надо заметить, что деятельность гильдий приводила ex post к реализации коммерческих проектов, требовавших значительных затрат, влекущих множество рисков и, как следствие, дополняемых построением кооперационных конструкций и механизмов, обеспечивающих диверсификацию рисков. Легко обнаруживаемым эффектом процесса ассоциирования была относительная экономия для участвующих в подобной организации отдельных лиц. Другие экономические, так же как и институциональные, следствия и мотивы рассматриваются ниже и обобщаются в таблицах 1 и 2.

В значительной мере условия для формирования институтов ассоциированного участия в бизнесе были продиктованы рядом факторов, влияющих на характер функционирования торговой отрасли Средневековья (см. табл. 1). Действие данных факторов оказало решающее влияние для образования особых типов экономической организации - купеческих гильдий, товариществ, торговых компаний, обществ, становившихся самостоятельными рыночными агентами. Выделим наиболее значимые из выявленных факторов, характеризующие условия функционирования данной отрасли хозяйства. Это высокая капиталоемкость бизнеса; высокие удельные издержки и низкая норма прибыли при малых объемах торговли, доступных разрозненным торговцам; узость рынков сбыта; наличие фактора риска, действующего в виде нестабильности закупочных цен и уровня издержек, чрезмерных накладных расходов, высокой вероятности значительных потерь при перевозках; наличие на многих рынках острой конкуренции и значительное число потенциальных конкурентов, готовых зайти на рынок; наличие фактов недобросовестной конкуренции (в виде мошенничества, сговоров и пр.); давление со стороны власти (вплоть до произвола); риск непосредственного насилия (со стороны недружественных народов или разбойничающих группировок) и т. д.

В ответ на данные факторы можно было наблюдать реакцию, выражавшуюся в формировании определенной мотивации и действиях, имевших в конечном итоге суммарный вектор в виде тенденции к образованию ассоциированных предприятий-корпораций в рассматриваемой отрасли. К таким мотивам и действиям следует отнести заключение партнерских контрактов, в числе прочего укрупняющих капитал в общих предприятиях; стремление отдельных агентов сократить издержки на единицу продаваемого товара, добиться понижения закупочных цен и повышения нормы прибыли благодаря преимуществу

крупных оптовых закупок и т. п., что было возможно только при условии объединения в группы и достижения некоторого эффекта масштаба; стремление отдельных агентов снизить издержки взаимодействия и риск, проявляющийся в оппортунистическом поведении на свободном рынке (что, как оказалось, также было достижимо только посредством создания устойчивых форм экономической организации, выработки внутренних правил и принципов организации внешних контактов); стремление отдельных агентов добиться устойчивого контроля рынка и цен (что требовало согласованных действий); стремление добиться защиты от недобросовестной конкуренции, недружественного использования «административного» и военного ресурсов, насилия со стороны пиратов (что также было возможно при ассоциированном участии); стремление самим использовать правительственные полномочия и военную силу в достижении коммерческих целей. 
Факторы и предпосылки развития форм ассоциированного хозяйствования, XI-XVIII века

\begin{tabular}{|c|c|c|}
\hline Правовые & Экономические & Исторические \\
\hline $\begin{array}{l}\text { Из предшествующих эпох: } \\
\text { - Изобретение римлянами понятия } \\
\text { (конструкции) юридического лица. } \\
\text { Из рассматриваемой эпохи: } \\
\text { - Построение модели корпорации, } \\
\text { корпоративного правового образования } \\
\text { (universitas) аббатом Клюни Одилоном } \\
\text { (994-1049) [Берман, 1998], а позднее } \\
\text { — папой Григорием VII в ходе так } \\
\text { называемой «папской революции» } \\
\text { (1075-1122 г.) [Берман, 1998]. } \\
\text { - Развитие торгового права (Lех } \\
\text { Меrсаtогіа) (XI-XVIII вв.). } \\
\text { - Развитие корпоративного права (XI- } \\
\text { XVIII вв.). } \\
\text { - Развитие концепции групповой } \\
\text { личности и ее реализация в принципе } \\
\text { неограниченной ответственности. } \\
\text { - Применение и развитие принципа } \\
\text { ограниченной ответственности в } \\
\text { конструкциях некоторых } \\
\text { разновидностей товариществ и } \\
\text { компаний (X-ХVI вв.). } \\
\text { - Развитие судебной практики в } \\
\text { урегулировании споров, касающихся } \\
\text { вопросов управления корпорацией (XI-- } \\
\text { ХVIII вв.). } \\
\text { - Практика закрепления особого } \\
\text { статуса или передачи привилегий и }\end{array}$ & $\begin{array}{l}\text { - Рост городов, разделение труда и развитие специализации, прогресс } \\
\text { денежного хозяйства. } \\
\text { - Потребность в крупных капиталах для совершения коммерческих } \\
\text { предприятий при дефиците частных капиталов и действии института } \\
\text { дерожеанции. } \\
\text { - Возможность избежать или значительно снизить индивидуальные } \\
\text { коммерческие риски. } \\
\text { - Возможность достижения экономии от кооперации, а в } \\
\text { последующем - от масштаба предприятия. } \\
\text { - Возможность достижения монопольной власти и усиления } \\
\text { экономического могущества за счет обретения политического } \\
\text { влияния. } \\
\text { - Возможность достижения экономического эффекта от } \\
\text { диверсификации продукта. } \\
\text { - Возможность устранения (смягчения) риска непредсказуемости } \\
\text { действий и проявления оппортунизма контрагентов в цепочке } \\
\text { «продавец - покупатель». } \\
\text { - Возможность устранения (смягчения) риска действий } \\
\text { конкурирующих партнеров, нарушающих оптимальное statиs qио в } \\
\text { угоду сиюминутной выгоде и во вред другим участникам рынка. } \\
\text { - Факторы, характеризующие специфику торговой отрасли, как } \\
\text { колыбель форм ассоциированного хозяйствования: } \\
\text { - высокая капиталоемкость бизнеса; } \\
\text { - высокие удельные издержки и низкая норма прибыли при малых } \\
\text { объемах торговли, доступных разрозненным торговцам; } \\
\text { - сложность получения кредита; } \\
\text { - узость рынков сбыта; } \\
\text { - наличие фактора риска, действующего в виде нестабильности } \\
\text { закупочных цен и уровня издержек, чрезмерных накладных }\end{array}$ & $\begin{array}{l}\text { - Формирование четкой } \\
\text { политической карты в } \\
\text { Европе. } \\
\text { - Великие географические } \\
\text { открытия XV-XVI вв. } \\
\text { - Активное соперничество } \\
\text { стран за контроль над } \\
\text { каналами доставки товаров } \\
\text { и, как следствие, } \\
\text { государственное } \\
\text { покровительство крупным } \\
\text { компаниям. } \\
\text { - Церковные расколы и } \\
\text { формирование } \\
\text { протестантской этики. } \\
\text { - Частное покровительство } \\
\text { и участие влиятельных особ } \\
\text { в компаниях. } \\
\text { (На более позднем этапе - с } \\
\text { ХVIII в. - участие } \\
\text { представителей средних } \\
\text { слоев общества.) }\end{array}$ \\
\hline
\end{tabular}




\begin{tabular}{|c|c|c|}
\hline Правовые & Экономические & Исторические \\
\hline $\begin{array}{l}\text { концессий. } \\
\text { - Изобретение юридических } \\
\text { конструкций типа «корпорация } \\
\text { имущества» (universitas bonorum), } \\
\text { затем - «фонд» (англ. «foundation») }\end{array}$ & $\begin{array}{l}\text { расходов, высокой вероятности значительных потерь при } \\
\text { перевозках; } \\
\text { - наличие на многих рынках острой конкуренции, как правило, } \\
\text { ценовой и значительное число потенциальных конкурентов, } \\
\text { готовых зайти на рынок; } \\
\text { - проявление мошенничества, сговоров, использования рычагов } \\
\text { давления со стороны власти и прочих фактов недобросовестной } \\
\text { конкуренции; } \\
\text { - риск транспортировки товаров, вытекающих из технологических, } \\
\text { природных, военно-политических и пр. обстоятельств. }\end{array}$ & \\
\hline
\end{tabular}


Факторы, влияющие на характер функционирования торговой отрасли, и

отвечающие им мотивы и действия ее участников, XI-XVIII века

\begin{tabular}{|c|c|c|c|c|}
\hline Факторы & $*$ & Мотивы и действия & $*$ & Результирующий вектор \\
\hline Высокая капиталоемкость бизнеса & & $\begin{array}{l}\text { Заключение партнерских контрактов, в числе прочего } \\
\text { укрупняющих капитал в общих предприятиях }\end{array}$ & & \\
\hline $\begin{array}{l}\text { Высокие удельные издержки и низкая } \\
\text { норма прибыли при малых объемах } \\
\text { торговли, доступных разрозненным } \\
\text { торговцам }\end{array}$ & & $\begin{array}{l}\text { Стремление агентов сократить издержки на единицу } \\
\text { продаваемого товара, добиться понижения закупочных } \\
\text { цен и повышения нормы прибыли благодаря } \\
\text { преимуществу крупных оптовых закупок и т. п. }\end{array}$ & & $\begin{array}{l}\text { Объединения торговцев в } \\
\text { группы для достижения } \\
\text { некоторого эффекта } \\
\text { масштаба }\end{array}$ \\
\hline $\begin{array}{l}\text { Нестабильность закупочных цен и } \\
\text { уровня издержек, чрезмерные } \\
\text { накладные расходы, высокая } \\
\text { вероятность значительных потерь при } \\
\text { перевозках (факторы делового риска) }\end{array}$ & & $\begin{array}{l}\text { Стремление отдельных агентов снизить издержки } \\
\text { взаимодействия и риск, проявляющийся в } \\
\text { оппортунистическом поведении на свободном рынке }\end{array}$ & & $\begin{array}{l}\text { Создание устойчивых } \\
\text { форм экономической } \\
\text { организации, выработка } \\
\text { внутренних правил и } \\
\text { принципов организации } \\
\text { внешних контактов }\end{array}$ \\
\hline Узость рынков сбыта & & $\begin{array}{l}\text { Стремление отдельных агентов добиться устойчивого } \\
\text { контроля рынка и цен }\end{array}$ & 4 & $\begin{array}{l}\text { Создание форм } \\
\text { взаимодействия с целью } \\
\text { осуществления } \\
\text { согласованных действий }\end{array}$ \\
\hline $\begin{array}{l}\text { Наличие на рынках острой } \\
\text { конкуренции, как правило, ценовой, и } \\
\text { значительное число потенциальных } \\
\text { конкурентов, готовых зайти на рынок }\end{array}$ & & $\begin{array}{l}\text { Стремление добиться защиты от недобросовестной } \\
\text { конкуренции, недружественного использования } \\
\text { «административного» и военного ресурсов, насилия со } \\
\text { стороны пиратов }\end{array}$ & 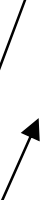 & $\begin{array}{l}\text { Создание крупных } \\
\text { ассоциированных } \\
\text { предприятий, } \\
\text { опирающихся не только на }\end{array}$ \\
\hline $\begin{array}{l}\text { Наличие фактов недобросовестной } \\
\text { конкуренции (в виде мошенничества, } \\
\text { сговоров и пр.), давления со стороны } \\
\text { власти и непосредственного насилия }\end{array}$ & & Необходимость снаряжения конвоев & & $\begin{array}{l}\text { экономические } \\
\text { возможности, но и на } \\
\text { политическую и военную } \\
\text { силу }\end{array}$ \\
\hline
\end{tabular}

* Причинно-следственные связи. 


\section{3. Особенности эволюции и значение гильдий}

Одним из первых шагов в раскрытии возможностей институтов экономической организации, ориентированных на решение проблем функционирования (в том числе финансирования) торговой отрасли, было создание модели купеческих гильдий. Становление данной формы организации ведения дел происходило в XI-XIII веках. Гильдии были устроены по всем канонам цехового института. Эти «ассоциации торговцев» служили интересам купцов и определяли место каждого из своих членов в сословной системе. Они являлись организационной формой, снижающей риски, возникающие вследствие непредсказуемости действий как их контрагентов (так как таким контрагентам могло становиться невыгодным проявление оппортунизма в случаях, когда им противостояли не отдельные купцы (рынок), а крупная сплоченная организация, регламентирующая действия своих членов), так и партнеров по цеху, являющихся прямыми конкурентами и в определенных ситуациях способных своими действиями нарушить рыночное равновесие в угоду сиюминутной выгоде, но во вред другим участникам рынка (что также может быть охарактеризовано как оппортунизм, относящийся к одному горизонту участников процесса рыночного взаимодействия). И тот и другой ожидаемые эффекты от объединения торговцев в гильдии обеспечивали стабильность и непрерывность отношений, и если называть экономическую организацию имеющей «целью обеспечение непрерывности отношений сторон путем создания специализированных структур управления их взаимодействием» [Уильямсон, 1996; O.E. Williamson, 1985], то это весьма точно относится к гильдиям.

Наиболее известными странами, внедрившими институт гильдий, были Германия и Англия. Первое упоминание о существовании купеческой гильдии в Англии относится к 1093 году. Среди характеристик гильдий, предлагаемых разными авторами, главное место занимают, во-первых, их четкое отношение к отдельной специализированной хозяйственной сфере; во-вторых, закрепление этого «структурного статуса» особыми привилегиями, даваемыми им органами светской власти. У.Дж. Эшли дал следующее определение такой ассоциации: «Купеческой гильдией, или ганзой... называлась ассоциация купцов, имевшая первоначально целью получение и охранение членами гильдии привилегии, которой не имели другие обитатели того же города, - торговать в его пределах, пользуясь монополией, а также приобретение права торговать в других городах» [Эшли, 1897].

Значение складывавшегося в связи с появлением гильдий в системе организации хозяйства порядка, при котором отдельно взятая гильдия контролировала либо какой-то товар или группу товаров, либо торговый институт, либо территорию и т.п., распространялось как на конфигурацию отношений в рамках всего рынка целиком, так и на конфигурацию отношений внутри самих гильдий. То, что институт гильдий, ганз и некоторых других ассоциаций в торговле испытывал сильную зависимость от поддерживающих его привилегий (во многих случаях бывших монопольными) в своем сегменте, хорошо осознавалось их участниками. Такое осознание вполне естественно сказывалось на внутренней организации гильдий. Эта внутренняя организация, включающая черты регламентации, была построена на принципе совместного владения привилегией (монополией) и нацелена на сохранение этой привилегии (монополии), дающей достаток ее участникам.

В различных средневековых государствах среди основных установок соответствующей регламентации были устраняющие внутреннюю конкуренцию: запрещение запродаж; запрещение соглашений на установку цен; право на вступление со своей долей в договор купли совместно с другими членами ассоциации и обязательство предоставления такого права другим и т.д. Получение прав (зафиксированных в хартиях, концессиях и подобных им документах), дававших возможность завоевания гильдиями, а позднее - первыми акционерными компаниями монопольного положения, должно быть также принято как серьезный стимул для их организации. Однако методы охранения (как внутреннего, так и 
внешнего) монополий, принадлежащих гильдиям, были не столь эффективны, так как не являлись частью политического процесса и не имели серьезных экономических оснований для своего развития. Это позволяет предположить, что отмеченные составляющие вместе с такими факторами, как неспособность гильдий к саморазвитию, слабость перед другими конкурирующими формами предприятий и т. д., предопределившие низкую устойчивость таких форм предприятий, приведут к скорой их смене иными формами.

Закат гильдий связывается как с социальными, так и с экономическими причинами, среди которых - разрушение сословного строя, расширение спектра деятельности деловых предприятий, географии торговли, открытие новых рынков, что в совокупности служило основой для снижения ценности обладания монопольными привилегиями для гильдий. Большое значение имели и государственные решения в данной области, составлявшие основу экономической политики того времени и закладывавшие принципы экономической организации на уровне как субъектов, так и рынков. Например, в Англии действовавшие почти три века гильдии прекратили свое существование к середине XIV столетия, что произошло, по утверждению У.Дж. Эшли, вследствие действия последней из обозначенных причин: непосредственному их закату предшествовало издание в 1335 году королевского указа, предоставлявшего иностранным купцам право на почти полную свободу торговли в стране. Указ фактически отменял привилегию купцов - членов гильдий на монопольное ведение местной торговли. В результате с 1351-го по 1377 год, в период проведения политики свободы торговли, самоликвидировались или потерпели крах почти все английские гильдии в торговле.

Упадок гильдий означал, что проблема организации и финансирования торговой отрасли должна была решаться с использованием иных форм ассоциированного участия в бизнесе (периодизация процессов появления, заката и трансформации, а также важнейшие характеристики форм деловых предприятий в Европе даны в табл. 3).

\section{4. Особенности эволюции и значение института товарищества. Комменда}

Гильдии изначально были не единственной формой совместного ведения дел в торговой отрасли эпохи Средневековья, вносившей определенный порядок и организацию в еe работу. Другой формой была комменда (commenda). Как тип организации экономического взаимодействия в рамках дальней морской торговли, она появилась в Италии еще в IX$\mathrm{X}$ веках. В данный период с ростом городов, развитием ремесел и активизацией торговых связей итальянских городов с Византией, Ближним Востоком, Африкой и Испанией наблюдался процесс накопления индивидуального богатства. Некоторые его обладатели, желавшие извлекать прибыль из торговых оборотов с заграницей, сами не имели либо возможности, либо достаточной смелости для личного сопровождения товаров, или оценивали как неприемлемый уровень риска таких путешествий. В связи с этим появился обычай поручать совершение торговых круизов агентам-представителям, оформляя это особыми соглашениями. Такие соглашения послужили основой для формирования в Средние века самой ранней формы товарищества- комменды.

Существовали разные вариации организации этого предприятия. Во всех случаях общим являлось то, что соглашение урегулировало действия двух компаньонов: одного коммендатора (или станса), оставшегося на месте и покрывавшего большую часть (до $100 \%$ ) затрат на предприятие, и другого - трактатора, готового лично сопровождать товар и в некоторых случаях вкладывавшего в дело капитал, составлявший не более $30 \%$ стоимости предприятия. Обычно станс обещал трактатору четвертую часть прибыли, и трактатор не участвовал своим капиталом в предприятии. В случае удачи трактатор имел возможность получить достаточную сумму для вложения в поездку также и своей доли. Независимо от этого трактатор мог заключить соглашения с несколькими коммендаторами одновременно. Тогда трактатор все больше становился фактическим организатором, руководителем (директором) предприятия (эволюция системы контрактации в институте 
комменды дана на рисунке 1). Такое предприятие могло представлять собой одновременно и примитивное долевое общество, и произвольное (не скрепленное юридически) объединение нескольких самостоятельных товариществ.

Важным признаком комменды стал принцип ограниченной ответственности: «Мерилом общей ответственности участника предприятия [принято считать] участие его в качестве собственника в управлении делом», - указывал У.Дж. Эшли [Эшли, 1897]. Таким образом, ответственность товарищей, не принимавших участия в непосредственном управлении предприятием, определялась исключительно размерами капитала, который каждый из них в отдельности рискнул вложить в предприятие.

Начальный этап

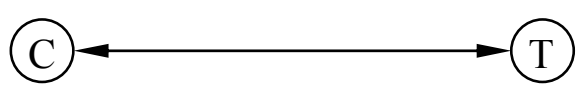

Промежуточный этап

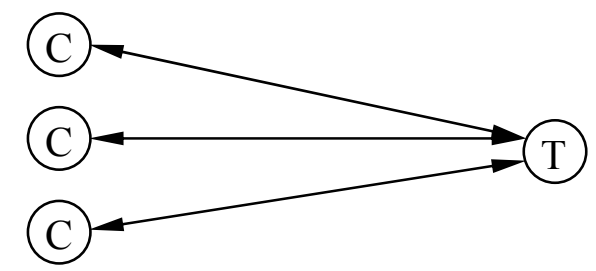

Конечный этап

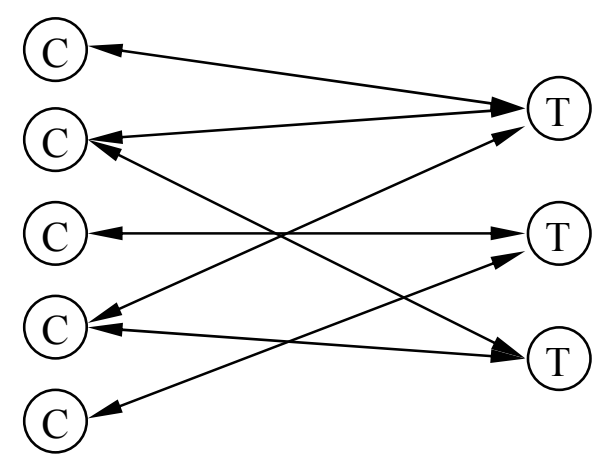

a) единственный коммендатор - единственный трактатор

б) единственный трактатор множество коммендаторов

в) множество коммендаторов во взаимодействии со множеством трактаторов

Рисунок 1. Система контрактации в институте комменды (эволюция)

Характеристика комменды обнаруживает существенные отличия данного института от института гильдий. Комменда совершенно не содержит влияния мотива, обозначенного выше как устранение непредсказуемости действий контрагентов, а также мотива упреждения действий, направленных на извлечение личной выгоды в ущерб интересам иных участников рынка. Вместо этого мы видим открытость основанных на модели комменды предприятий (и их участников) воздействию со стороны конкуренции и подверженность множеству рисков. Вместе с тем заложенная в комменде модель взаимодействия партнеров (в том числе по линии инвесторов, являющихся потенциальными конкурентами), основанная на принципе ограниченной ответственности, позволяла выстроить свою технологию смягчения рисков, что очень важно, не в ущерб конкуренции.

Это отчетливо обнаружилось, когда капитал одного товарищества стал собираться от нескольких учредителей и одновременно коммендаторы стали делить свой капитал между несколькими коммендами. Указание на это, в частности, делает Р. Камерон, утверждая, что в Генуе и других итальянских городах еще в XII веке многие из тех, кто не занимался активной торговой деятельностью, вкладывали в торговлю свои средства через механизм партнерств, подобных комменде [Камерон, 2001].

Отметим, что комменда отличалась от возникшей в более поздний период формы акционерной компании. Назовем основные и наиболее существенные различия. Bo-nepвыx, комменда являлась краткосрочным соглашением, которое расторгалось по окончании коммерческого круиза, ради которого она учреждалась. Краткосрочность комменды служила 
некоторым оправданием для того, что серьезных мотивов к выработке практик трансфертав данной сумме контрактов не возникало. Bo-вторых, право на капитал в комменде (в отсутствие инструмента, обеспечивавшего такой оборот - акции) не могло свободно переходить из одних рук в другие. Однако уже в XIV веке произошли изменения, приблизившие институт товариществ к форме акционерной компании. Речь идет о появлении товариществ на вере (примером могут служить компании Барди и Перуцци товарищества, не ограничивавшие свое существование сроком какого-либо одного плавания), в еще более позднее время трансформированных в акционерную форму товариществ («коммандиты на акциях»), предполагавших оборот документов, удостоверявших вклад коммандидистов в капитал товариществ [Тарасов, 1878, 2000].

\section{5. Эволюция компаний и товариществ на акциях}

Комменда не являлась единственной ранней формой товарищества. За пределами Италии и контролируемых итальянскими республиками центров были известны другие его формы, такие как английское торговое товарищество, германское «открытое товарищество» и пр. Основой образования английского торгового товарищества, его прототипом, явилась форма предприятия, получившая название «компания». Поначалу это были не менее тесные, чем гильдии, ассоциации компаньонов, в которых делилось все: пища, каждодневный риск, капитал и труд (что подтверждает разбор слова «ком-пания»: cum - вместе, panis - хлеб). Дисциплина, организующая торговцев, состоявших в компании, была аналогична той, которую навязывали своим членам цехи и гильдии. Помимо порядка вступления в компанию посредством уплаты взноса предусматривалась и возможность приобретения права членства наследственным путем или по окончании ученичества. Эти признаки дают основания причислить ранние компании к институтам цехового строя, так же, как и гильдии. Еще один важный признак ранней формы компании - неограниченная ответственность участников. Как правовой институт и одновременно принцип организации бизнеса, он отчасти ведет свое начало от совместной жизни членов компаний, а также обязан правовой традиции, защищающей концепцию групповой личности.

В период XIV-XVIII веков в Англии форма товарищества, основанная на принципе неограниченной ответственности, почти вытеснила построенную на принципе ограниченной ответственности более раннюю, возникшую из комменды форму. Неограниченная ответственность лежала также и в основе германской концепции ассоциации. Указанные тенденции свидетельствуют в пользу того, что возникшие в обозначенный период формы предприятий достаточно чутко отвечали таким мотивам ассоциирования их участников, как смягчение или устранение неопределенности, «субъективного риска» и, более широко, оппортунистического поведения (как сказано выше, рассматриваемого в данном случае не в цепочке «продавец - покупатель», а в плоскости взаимодействия конкурирующих между собой продавцов/покупателей). Причем, на наш взгляд, таких целей участники товариществ и компаний достигали безотносительно того, организованы они на принципах ограниченной или неограниченной ответственности; однако последняя форма сильнее дисциплинировала участников. Более позднее изменение форм предприятий и структуры, указывающей на долю каждой из них (форм) в выпуске, занятости и пр., при сохранении обозначенных выше мотивов, свидетельствует о силе (если не сказать превалировании) экономикотехнологических мотивов (экономия от масштаба и горизонтальная интеграция, эффект от диверсификации продукта и пр.) в данном процессе.

На исходе Средневековья система товариществ, так же как и система гильдий, исчерпала себя как лидирующий институт, превалирующая форма в подотрасли крупной морской торговли. Цеховые порядки, присутствовавшие в организации компаний, плюс сложности со свободой вложения и изъятия капитала в товариществах, а также краткосрочный характер комменды, как явные недостатки имевшихся форм и факторы сдерживания развития деловой практики, побудили стремление к поиску новой, более 
совершенной формы организации бизнеса. Базовые юридические принципы и основы новых ассоциаций были заимствованы из проанализированной выше комменды. Однако способы финансирования, вложения и изъятия капитала участниками постепенно становились более совершенными и преимущественно в корне отличающимися от обнаруживаемых в цеховых институтах.

Тем не менее начало этой эволюции можно было проследить как раз в цеховом институте, каковым, например, еще в XII веке в Германии являлась такая организационная форма предприятий, как Gewerkschaften. Она основывалась на принципе подчинения единоличных интересов сословным и предусматривала дробление участия на доли. Причем эти доли участия были отчуждаемы, имели рыночную цену (однако еще не было понятия акции, а имущественная ответственность участников могла превышать размер сделанного вклада) [Тарасов, 1878, 2000]. Кроме того, ранее XV века встречались отдельные случаи, когда средиземноморские корабли не только оказывались собственностью, разделенной на доли, но и, в отличие от условий, поддерживаемых правовым институтом комменды; такие доли переходили из одних рук в другие. Подобные прецеденты не являлись тем, что можно было бы считать открытой, или рыночной, торговлей, - скорее они были поиском легитимных форм возмездной передачи прав на долю в неделимом объекте собственности от одного лица другому. В конечном итоге такая практика (наряду с опытом функционирования предприятий других форм) послужила важным этапом эволюции, приведшей к формированию института акционерных обществ, появлению в деловом обороте долевой ценной бумаги - акции и развитию рынка акций (рынка капитала, фондового рынка).

Важным звеном данной эволюции стало появление в XVI-XVII веках компаний, названных англичанами Joint Stock Companies, то есть компаний объединенного капитала (совместных фондов), которые сформировали эволюционную ветвь акционерных компаний ${ }^{13}$. Приобретая долю в торговом (или любом другом) предприятии, имевшем форму акционерной компании, средневековый инвестор вступал в права совладения с такими же инвесторами, как и он ${ }^{14}$. Ограниченность ответственности такого инвестора позволяла предпринять попытку поиска формы передачи прав, а высокое развитие оборота гражданских документов к тому времени могло служить существенным фактором для изменения статуса доли участника компании. Появившаяся вскоре практика оборота (куплипродажи) подобных долей (юридическим основанием для которой служил институт цессии) выступала при этом как тенденция к образованию рынка, на котором бы уравновешивался спрос на новый «товар» - комплекс прав, воплощенных в доле собственности на предприятие, а впоследствии - в особой ценной бумаге - акции. Заметим, что основной характеристикой, потребительской стоимостью этого товара являлась его способность приносить доход, так что данный товар в полной мере отвечал термину «товар-капитал», а рынок, на котором он обращался, - термину «рынок капиталов».

Однако от появления первых акционерных компаний до окончательного становления рынка капитала было весьма далеко: необходимо было усовершенствовать стандарт такого товара (финансового инструмента, акции), сформировать единообразный порядок его производства (эмиссии), унифицировать правила рыночных операций с ним, создать площадку для торговли. Все это заняло более 300 лет и было в той или иной степени завершено лишь к середине XIX века.

Начальный этап развития института акционерных компаний был и длительным, и сложным. Накопленного к середине XVI века опыта и правовой практики было недостаточно, чтобы реализовать идею создания компании совместных фондов как

\footnotetext{
13 Данное понятие превалировало вплоть до XX века, когда стало заменяться понятием «акционерное общество».

14 Это существенно отличало модель такой компании от модели товарищества на вере, в котором участники делились на полных товарищей (обладавших вследствие этого исключительными полномочиями в управлении) и вкладчиков (коммандидистов, депонентов), рисковавших лишь доверяемым капиталом и не имевших права вмешиваться в процесс управления.
} 
непрерывно действующей бизнес-структуры. Предшествовавшая акционерным компаниям форма товарищества определяла некоторые начальные стандарты для функционирования новых форм деловых предприятий. В итоге первые звенья эволюции акционерных компаний - это предприятия, изначально планируемые на одну сделку или поездку (подобные комменде), по сути, разовые контракты; несколько позднее - соглашения, связывающие пайщиков-акционеров на определенный срок (но не дольше полутора - двух лет); и лишь к концу XVII века - предприятия с неизымаемым акционерным капиталом.

Амбициозность целей, которые ставили перед собой учредители компаний, порождали сложности, так сказать, разрешительного порядка. В результате организация таких предприятий нередко становилась обязанной либо личной унии его участников с местными или королевскими властями, либо явной заинтересованности в них со стороны влиятельных структур (муниципалитетов, государства, орденов) или привилегированных особ.

Обратимся к примерам. Первыми из известных нам акционерных обществ были английские «Англо-Гамбургская торговая компания» [Тарасов, 1878, 2000] и «Московская компания» (образованы в 1550-х годах) [Бродель, 1986]. Далее следуют английские «Испанская» (1577), «Балтийская» (1579) компании, «Левантийская (Турецкая)» компания (1583). Спустя два десятилетия к ним присоединились энциклопедически известные английская и голландская «Ост-Индские» компании ${ }^{15}$; в 1611 году учреждена английская «Французская» компания. Самими французами уже в XVII веке учреждались компании: de la Nouvelle France (1628), du Senegal (1651), des Indes Occidentales (1664) и др. [Hерсесов, 1889, 2000].

Несмотря на однородные названия, компании могли иметь разную внутреннюю форму организации. К началу XVII века окончательно сформировались два типа компаний: регламентируемые, представлявшие собой ассоциации предпринимателей, каждый из которых управлял своим собственным делом и получал свою прибыль отдельно, но осуществлялось это под защитой общих привилегий и подлежало регулированию; и компании со складочным капиталом - являвшиеся ассоциациями лиц, отвечающих в деле вложенным капиталом [Кочетков, Супян, 2005]. Компании могли менять свой статус. Так, например, основанная в 1581 году «Левантинская компания» в 1605-м была регламентирована.

«Англо-Гамбургская торговая», «Московская» «Северная» и «Левантийская» компании имели следующие регламенты, отвечающие признакам товарищеской организации: «пайщики были выборные, могли быть исключаемы по постановлению общего собрания за предосудительное поведение и т. п.» [Тарасов, 1878, 2000]. Английская «Ост-Индская» компания в первое время могла называться акционерной лишь в том смысле, что представляла собой организацию, периодически аккумулировавшую путем объединения долей капитал для одного плавания, по возвращении из которого каждый купец-акционер получал не только свои прибыли, но и обратно свой пай. Начиная с 1612 года счета составляются на ряд предполагаемых экспедиций ${ }^{16}$, а с 1658 года акционерный капитал становится неизымаемым.

Последовавшие за этим важные организационные и институциональные инновации позволили уже через 30 лет, в 1688 году, начать открытую продажу английской Ост-Индской компанией своих акций на Королевской бирже в Лондоне. Таким образом, вторую половину XVII века следует рассматривать как ключевой этап истории эволюции института акции и развития фондового рынка.

\footnotetext{
${ }^{15}$ И.Т.Тарасов отводит первенство в акционерном деле итальянцам (называя пример генуэзского банка Святого Георгия), а также на одной из страниц своего известного «Учения об акционерных компаниях» говорит, что развитие акционерного дела последовало сначала в Голландии («Compagnie von Veere», 1595), а уже затем в Англии [Тарасов, 1878, 2000].

${ }^{16}$ В том же 1612 году, как сообщает Р. Камерон, голландская Ост-Индская компания приняла «постоянную» форму, т. е. стала организацией, при которой держатель акций мог выйти из компании, только продав свою долю другому инвестору [Камерон, 2001].
}

Выпуск \#2(6), 2008 С Электронный журнал Корпоративные Финансы, 2008 
Ассоциированные формы коммерческих предприятий, как показала история, оказались востребованным и быстро прогрессирующим институтом. Многообразие этих форм, процесс, который характеризовался появлением, расцветом и закатом некоторых из них, изменение во времени их структуры и содержания и одновременно перенесение некоторых ключевых признаков вполне могут служить основаниями для рассмотрения данного процесса в терминах эволюционной экономики. Здесь мы наблюдаем и своего рода естественный отбор, и «нащупывание» в поиске удобных типов предприятий, и их адаптацию к условиям внешней среды, и перенесение признаков при изменении форм, и непременные видоизменения. Многообразие и гибкость форм, безусловно, повышали адаптивность бизнеса к меняющимся ситуациям и условиям, а следовательно, были востребованы системой. Объем настоящей статьи не позволяет остановиться на всех формах предприятий, известных в доиндустриальный период, показать в развернутом виде основания тех тенденций, которые наблюдались в эволюции ассоциированных форм предприятий. В заключение предлагается сжатое обобщение этого вопроса, представленное в виде таблицы 3.

Таблица 3

Эволюция форм ассоциированных предприятий, XI-XX века

\begin{tabular}{|c|c|}
\hline $\begin{array}{c}\text { Форма } \\
\text { предприятия; } \\
\text { периодизация } \\
\text { эволюции }\end{array}$ & Характеристика \\
\hline $\begin{array}{l}\text { Гильдии, } \\
\text { Guilds. } \\
\text { Появление: } \\
\text { XI-XIII вв. } \\
\text { Закат: XIV- } \\
\text { XVIII вв. }\end{array}$ & $\begin{array}{l}\text { - Институты цехового строя. } \\
\text { - Определяют место каждого из своих членов в сословной системе. } \\
\text { Поддерживают порядок, при котором члены придерживались } \\
\text { религиозных, нравственных норм. } \\
\text { - Имеют целью получение и охранение членами гильдии данной ей } \\
\text { привилегии. } \\
\text { - Имеют внутренние регламентации, устраняющие внутреннюю } \\
\text { конкуренцию: запрещение запродаж; запрещение соглашений на } \\
\text { установку цен; право на вступление со своей долей в договор купли } \\
\text { совместно с другими членами, обязательство предоставления такого } \\
\text { права другим и т. д. } \\
\text { - Испытывают зависимость от сохранения полученных привилегий. } \\
\text { - Оказываются неустойчивыми образованиями и распадаются в } \\
\text { условиях открытой и неограниченной чьими-то исключительными } \\
\text { правами конкуренции рыночных агентов }\end{array}$ \\
\hline $\begin{array}{l}\text { Комменда, } \\
\text { Соттепda. } \\
\text { Появление: } \\
\text { IX-X вв. } \\
\text { Закат: XVII- } \\
\text { XVIII вв. }\end{array}$ & $\begin{array}{l}\text { - Разновидность института товарищества. } \\
\text { - Определяет порядок взаимодействия хозяйствующих субъектов, } \\
\text { выражаясь современным языком, - лиц, инвестирующих свой капитал } \\
\text { или свой труд и управляющих. } \\
\text { - Закрепляет принцип ограниченной ответственности, согласно } \\
\text { которому инвесторы несут ответственность в пределах } \\
\text { инвестированной в товарищество суммы, а товарищество не отвечает } \\
\text { по обязательствам инвесторов. } \\
\text { - Предусматривает возможность участия в предприятии множества } \\
\text { инвесторов и возможность одного инвестора быть участником } \\
\text { множества товариществ. } \\
\text { - Коммерческий успех зависит от множества факторов, в числе } \\
\text { которых наличие привилегий или концессий не имеет исключительно } \\
\text { важного значения. } \\
\text { - Представляет собой краткосрочное соглашение, расторгаемое по } \\
\text { окончании коммерческого проекта. }\end{array}$ \\
\hline
\end{tabular}




\begin{tabular}{|c|c|}
\hline $\begin{array}{l}\text { Форма } \\
\text { предприятия; } \\
\text { периодизация } \\
\text { эволюции }\end{array}$ & Характеристика \\
\hline & $\begin{array}{l}\text { - Права, вытекающие из участия в комменде, не могут свободно } \\
\text { переходить из одних рук в другие. } \\
\text { - Преемственные формы обрела в лице акционерных компаний и } \\
\text { коммандитных товариществ }\end{array}$ \\
\hline $\begin{array}{l}\text { «Трудовые } \\
\text { товарищества» в } \\
\text { горнорудной } \\
\text { промышленности. } \\
\text { Появление: } \\
\text { XIII в. } \\
\text { Закат: XV в. }\end{array}$ & $\begin{array}{l}\text { - Разновидность института товарищества. } \\
\text { - На начальном этапе до́лей являлось непосредственное трудовое } \\
\text { участие человека в разработке недр. } \\
\text { - Как результат, сильная раздробленность и сильное распыление } \\
\text { получаемого дохода. } \\
\text { - С XV в. повышается доходность предприятий, трудовые паи } \\
\text { сменяются денежными. } \\
\text { - Паи приобретают свойство обращаемости, происходит отток } \\
\text { собственности на горные предприятия от непосредственно занятых в } \\
\text { разработках к иным лицам, собственность концентрируется в руках } \\
\text { отдельных лиц или компаний, совершается переход к использованию } \\
\text { наемного труда. } \\
\text { - Трансформируются в артельные формы либо подвергаются } \\
\text { поглощению со стороны крупных торгово-банковских домов и } \\
\text { металлургических предприятий, выстраивающих вертикально- } \\
\text { интегрированные структуры }\end{array}$ \\
\hline $\begin{array}{l}\text { Gewerkschaften. } \\
\text { Появление: } \\
\text { ХІІ-ХIII вв. } \\
\text { Трансформация: } \\
\text { нет данных }\end{array}$ & $\begin{array}{l}\text { - Разновидность института товарищества, появившаяся в Германии. } \\
\text { - Основывалось на принципе подчинения единоличных интересов } \\
\text { сословным. } \\
\text { - Предусматривало дробление участия на доли, причем доли участия } \\
\text { были отчуждаемы и имели рыночную цену. } \\
\text { - Имущественная ответственность участников могла превышать размер } \\
\text { сделанного вклада. } \\
\text { - Предположительно могло трансформироваться к XV в. в форму } \\
\text { Gesellschaft [Тарасов, 1878, 2000], имевшую черты коммандиты на } \\
\text { акциях }\end{array}$ \\
\hline $\begin{array}{l}\text { Компания, } \\
\text { Сотрапіа. } \\
\text { Появление: } \\
\text { XI-XII вв. } \\
\text { Трансформация: } \\
\text { XV-XVI вв. }\end{array}$ & $\begin{array}{l}\text { - Прототип английского торгового товарищества. } \\
\text { - Первоначально имела черты цеховой и общинной организации, } \\
\text { представляя собой союз членов, деливших между собой пищу, труд, } \\
\text { каждодневный риск и капитал. } \\
\text { - Предусматривает порядок вступления через уплату взноса, а также } \\
\text { через прохождение ученичества и наследственным путем. } \\
\text { - Закрепляет принцип неограниченной ответственности }\end{array}$ \\
\hline $\begin{array}{l}\text { Английское } \\
\text { торговое } \\
\text { товарищество. } \\
\text { Появление: } \\
\text { XV-XVI вв. } \\
\text { Закат: XVIII- } \\
\text { XIX вв. }\end{array}$ & $\begin{array}{l}\text { - Эволюционировало из компании, но организованные в этой форме } \\
\text { предприятия имели более крупные размеры. } \\
\text { - Сохраняло черты цеховой организации. } \\
\text { - Имело ограничения на свободу вложения и изъятия капитала. } \\
\text { - Основывалось на принципе неограниченной ответственности }\end{array}$ \\
\hline $\begin{array}{l}\text { Акционерные } \\
\text { компании, } \\
\text { Stock Companies. } \\
\text { Появление: }\end{array}$ & $\begin{array}{l}\text { - Прототип современных акционерных обществ. } \\
\text { - Имели две разновидности: регламентируемые компании и компании } \\
\text { со складочным капиталом. } \\
\text { - Регламентируемая представляла собой ассоциацию }\end{array}$ \\
\hline
\end{tabular}




\begin{tabular}{|c|c|}
\hline $\begin{array}{c}\text { Форма } \\
\text { предприятия; } \\
\text { периодизация } \\
\text { эволюции }\end{array}$ & Характеристика \\
\hline $\begin{array}{l}\text { XVI-XVII вв. } \\
\text { Tрансформация: } \\
\text { XIX в. }\end{array}$ & $\begin{array}{l}\text { предпринимателей, каждый из которых управлял своим собственным } \\
\text { делом и получал свою прибыль отдельно, осуществляя это под защитой } \\
\text { общих привилегий и подвергаясь регулированию. } \\
\text { - Компания со складочнылм капиталом являлась ассоциацией лиц, } \\
\text { отвечающих в деле вложенным капиталом. } \\
\text { - Не всегда базировались на принципе ограниченной ответственности, } \\
\text { так что различались три разновидности: компании с солидарной } \\
\text { ответственностью членов; компании с ответственностью до известной } \\
\text { суммы свыше акционерного капитала; компании с ответственностью } \\
\text { членов в сумме, ограниченной стоимостью акций. } \\
\text { - На ранней стадии объединение капитала могло предназначаться для } \\
\text { реализации одного коммерческого проекта (как правило, } \\
\text { трансграничного морского круиза), а пайщики имели право свободного } \\
\text { изъятия средств из компании. } \\
\text { - Во 2-й половине ХVІІ в. закреплена конструкция, согласно которой } \\
\text { акционерный капитал становится неизымаемым. } \\
\text { - Предусматривали право акционера свободно передать свои акции (и } \\
\text { вытекающие из них права) любому другому лицу. } \\
\text { - Трансформировались в акционерные общества (с ограниченной } \\
\text { ответственностью) во второй половине ХІХ века, что предполагало } \\
\text { использование в названии компании слова «limited». В ХХ веке } \\
\text { принято стало употребление в названии слова «согрогаtiоп» }\end{array}$ \\
\hline $\begin{array}{l}\text { Коммандитные } \\
\text { товарищества. } \\
\text { Появление: } \\
\text { XVI в. }\end{array}$ & $\begin{array}{l}\text { - Один из преемников средневековой комменды (коммандиты). } \\
\text { - Содержит разные категории участников: одни участники партнерства } \\
\text { несут неограниченную ответственность за результаты его } \\
\text { деятельности, другие рискуют только суммами, которые они внесли в } \\
\text { капитал товарищества }\end{array}$ \\
\hline $\begin{array}{l}\text { Акционерные } \\
\text { общества (АО), } \\
\text { Joint Stock } \\
\text { Companies, } \\
\text { Joint Stock } \\
\text { Corporations. } \\
\text { Появление: } \\
\text { XVIII-XIX вв. } \\
\text { Модернизация: } \\
\text { XX в. }\end{array}$ & $\begin{array}{l}\text { - Стали результатом эволюции как корпорации (в смысле формы } \\
\text { общественного объединения, устроенного с целью достижения } \\
\text { преимущественно публичных целей), так и акционерной компании и } \\
\text { акционерного банка. } \\
\text { - Результат заключался в том, что, во-первыхх, акционерная форма стала } \\
\text { универсальной для учреждения обществ, имеющих разную отраслевую } \\
\text { специализацию (торговля, страхование, транспорт, промышленность, } \\
\text { банковское дело); во-вторых, АО стали действительно общественной, } \\
\text { демократичной, доступной для неограниченного круга желающих } \\
\text { формой участия в их капитале, а следовательно, в достижении } \\
\text { поставленных ими целей. } \\
\text { - Связь между членами обществ ограничена целями, с которыми они } \\
\text { учреждаются и действуют; из неучастия акционеров в } \\
\text { непосредственном управлении фирмой логически вытекает оправдание } \\
\text { ограниченной ответственности членов. } \\
\text { - Модернизация АО заключалась в построении лучших моделей } \\
\text { корпоративного управления, закреплении принципов управления в } \\
\text { интересах акционеров и инвесторов, исповедании принципов } \\
\text { транспарентности и т. п. } \\
\text { - Имели место эксперименты по построению моделей управления, } \\
\text { лучшим образом подстроенных под выполнение рыночных задач и }\end{array}$ \\
\hline
\end{tabular}




\begin{tabular}{|c|l|}
\hline $\begin{array}{c}\text { Форма } \\
\text { предприятия; } \\
\text { эволизация }\end{array}$ & \multicolumn{1}{c|}{ Характеристика } \\
\hline & $\begin{array}{l}\text { бизнес-стратегий. Например, использование холдинговых моделей } \\
\text { позволяло реализовать возможность перехода от централизованной, } \\
\text { функционально специализированной формы организации предприятий } \\
\text { к более эффективно действующей децентрализованной, } \\
\text { многодивизиональной и т. д. }\end{array}$ \\
\hline
\end{tabular}

\section{Список литературы}

1. Берман Г. Дж. Западная традиция права: эпоха формирования. М.: Изд-во МГУ: Издательская группа ИНФРА-М - НОРМА, 1998.

2. Бродель Ф. Материальная цивилизация, экономика и капитализм, XV-XVIII вв. Т. II. Игры обмена. М.: Прогресс, 1986.

3. Камерон Р. Краткая экономическая история мира. От палеолита до наших дней. М.: Росспэн, 2001.

4. Кочетков Г.Б., Супян В.Б. Корпорация: американская модель. СПб.: Питер, 2005.

5. Криничанский К. В. Генезис экономических институтов: корпорации, профессиональные участники финансового рынка: Средневековая Европа современная Россия. Челябинск: Челяб. гос. ун-т, 2003.

6. Кулагин М. И. Избранные труды по акционерному и торговому праву. М.: Статут, 2004.

7. Нерсесов Н. О. Избранные труды по представительству и ценным бумагам в гражданском праве. М.: Статут, 2000.

8. Норт Даглас К. Институты и экономический рост: историческое введение// Thesis. 1993, вып. 2. - С. 69-91.

9. Тарасов И. Т. Учение об акционерных компаниях. М.: Статут, 2000.

10. Уильямсон О.И. Экономические институты капитализма: Фирмы, рынки, «отношенческая» контрактация. СПб: Лениздат; CEV Press, 1996.

11. Шумпетер Й.А. Теория экономического анализа. В 3-х т. СПб: Экономическая школа, СПГУЭиФ, ГУ ВШЭ, 2001.

12. Эшли У.Дж. Экономическая история Англии в связи с экономической теорией. М.: Издание М.И. Водовозовой, 1897. 